\title{
圧電アクチュエータ・センサを用いた CFRP 積層板の単一モード 振動制御*1 Single Modal Vibration Control of CFRP Laminated Plates Using a Pair of a Piezoelectric Actuator and a Sensor
}

\author{
亀山正 樹*2 ·和 田理 男 ${ }^{* 2} \cdot$ 福 永久 雄 ${ }^{2}$ \\ Masaki Kameyama, Yoshio WadA and Hisao Fukunaga
}

Key Words : Vibration Control, Modal Sensor/Actuator, Optimal Placement, Band-Pass Filter, Composite Materials

\begin{abstract}
The present paper treats a structural vibration control for a specific lower-order or higher-order single mode using the modal sensor and the modal actuator. In this paper, we examine the validity of modal sensor in the vibration measurement and control of CFRP cantilevered plates. A modal sensor system for identifying the specific vibration mode, which is mechanically simple, is developed by one accelerometer and one band-pass filter so as to be easily equipped to the structures. Here, the location of accelerometer is optimized based on the minimization criterion of observation spillover. Moreover, a modal actuator system to generate a modal control force for controlling the specific vibration mode is also developed by one piezoelectric patch. The location of PZT piezoelectric patch is also optimized and the independent modal space control based on the LQR control theory is applied in this research. The numerical and experimental results show that the proposed vibration control system is effective for suppression of single modal vibration regardless of a lower-order or higher-order modal vibration.
\end{abstract}

\section{1. 緒訔}

近年 , 宇宙用アンテナや人工衛星の太陽電池パドル等の 宇宙構造物は, 高性能化の要求からより一層の大型化・軽 量化が求められている. 兴の結果, 宇宙構造物は軽量かつ 柔軟となり，種々の外的要因により振動が生じやすくなる． なお, これらの振動は, 構造物の性能や健全性等に影響を およぼす可能性があることから，構造にセンサ・アクチュ エータを組み込むことにより知的構造物を構成し，受動的 あるいは能動的に振動を抑制するための研究が活発に行わ れている1,2). 本研究では, 少数のセンサと帯域通過フィル タを併用した機械的に簡便なモード別振動計測系を構築し， それを応用した振動制御に関する検討を行う。

構造物の振動制御においては, 多自由度系の振動をモー ド座標系へ射影することによって 1 自由度系の振動に帰着 させて考え, 多自由度系の振動に対して支配的な振動モ一 ドのみを制御する方法が多く用いられている．モードセン サ・モードアクチュエータ ${ }^{3)}$ を構築することにより振動を 各振動モードに分離して計測・制御を行う方法は, スピル オーバ不安定を生じにくい特徵を有するため, 近年活発に 研究が進められている. 本研究では, 特にモードセンサを 用いた構造物の振動計測に注目する .

モードセンサ構築に関する従来の研究では, 圧電素子を用 いたモードセンサ構築方法に関する検討が多くなされてい る . 例えば , はり・板に貼付する PVDF 圧電フィルムの形

\footnotetext{
*1 (C) 2009 日本航空宇宙学会

平成 20 年 8 月 21 日原稿受理

*2 東北大学大学院工学研究科航空宇宙工学専攻
}

状を最適化する方法 ${ }^{3 \sim 6)} や$, 構造の全面に貼付した PVDF 圧電フィルム上の電極配置を最適化する方法7), $\mathrm{PZT}$ 圧電 素子の大きさと配置箇所を最適化する方法8) 等が提案され ており, 数值シミュレーションと実験の両面から光の有効 性を明らかにしている.しかし, 従来提案されてきた方法 では, 大規模・複杂倠な構造への適用が困難であると考えら れる.一方, 著者らは, 大規模・複杂隹な構造への拡張が容易 な振動計測・制御方法として，加速度センサを用いたモー ドセンサと PZT 圧電素子を用いたモードアクチュエータ に関する検討を行っている ${ }^{9,10)}$. すなわち, 少数の加速度 センサと PZT 圧電素子を光れ光れ最適配置することによ りモードセンサ・モードアクチュエータを構築し , 数值シ ミュレーション9), および, 実験 ${ }^{10)}$ を通じて, CFRP 積層 板の振動計測・振動制御における有効性を示している．

以上のように，構造物の振動計測・振動制御に関する研 究はこれまで活発に行われている.しかし, 平板やシェル 構造等を対象とした振動計測においては, 多数の点計測セ ンサや大面積を有する圧電センサを用いてモードセンサを 構築しているのが現状であり, 大型・複杂倠な構造物への適 用に際してはさらに議論の余地がある．よって，より簡易 な方法を用いた振動計測・制御系の実現が望まれている .

なお，モード別振動制御においては，制御対象モード以 外の残余モードによるスピルオーバ不安定性を極力低減す ることが重要である.一般に, 構造物は振動モードと固有 振動数が一対一で対応しており, 残余モードの固有振動数 に対応する周波数領域を遮断することによりスピルオーバ 不安定を回避することが可能であることから，周波数フィ ルタを用いたモード別振動制御に関する研究も行われてい 
$3^{11)}$.

本研究では, 構造物への適用がより容易な振動計測系・ 制御系の構築を目的とし，必要とするセンサ個数の大幅な 低減を可能にする点計測センサを用いた振動計測系の設計 方法を提案する.

本論文の構成は次の通りである.初めに, 最適配置され た加速度センサと帯域通過フィルタを併用することにより 機械的に簡便なモード別振動計測系を構築する . センサ最 適配置においては観測スピルオーバ最小化規準に基づく定 式化を示し，1 個の加速度センサによって高精度の単一モー ド計測を実現する.乥して, 片持支持された CFRP 対称積 層板を対象とした振動計測の数值シミュレーションを行い， 構築した振動計测系を用いた際のモード速度推定精度につ いて検討する . 次に，片持 CFRP 対称積層板を対象とし， 構築したモードセンサを用いた振動計測実験を行い，光の 有効性を示す .さらに , モードセンサによって得られる推 定モード速度および推定モード変位に基づいた，モード別 状態フィードバック制御による振動制御について検討する． 1 個の PZT 圧電アクチュエータを最適配置箇所に貼付した 片持 CFRP 対称積層板を対象として振動制御実験を行い， 特定の低次および高次振動モードの抑制が可能であること を示す．

\section{2. 定式 化}

2.1 モードセンサ9) 本研究では, 構造物に貼付した 1 個の加速度センサおよび 1 個の帯域通過フィルタによって モードセンサを構筑する . 加速度センサによって得られた 加速度応答を帯域通過フィルタに通すことにより特定の周 波数帯域のみの加速度応答に変換し, モード変換を行うこ とによりモード加速度，モード加速度を時間に関して積分 することによりモード速度を得る.以降, 本節ではモード 変換の詳細について説明し, 帯域通過フィルタの詳細に関 しては 3.1 節において説明する .

2.1.1 加速度計測に基づくモード速度推定法 ここでは， 1 個の加速度センサを用いたモード速度推定法に関する定 式化を示す. 加速度センサは有限要素分割された平板の要 素節点上に配置され, 面外方向の加速度を計測するものと する . 有限要素解析に基づくと，加速度センサが配置され た節点に関して, 加速度 $\overline{\ddot{u}}$ とモード加速度 $\{\ddot{\eta}\}: N_{\text {mall }} \times 1$ の関係は次式で与えられる .

$$
\overline{\ddot{u}}=\{\bar{\Phi}\}\{\ddot{\eta}\}
$$

ここで， $N_{\text {mall }}$ は有限要素解析において考慮するモ一ド数 を表し, $\overline{\ddot{u}}$ および $\{\bar{\Phi}\}: 1 \times N_{\text {mall }}$ は光れ光れ，全自由度に 関する加速度べクトル $\{\ddot{u}\}$ および固有振動モードマトリッ クス $[\Phi]$ のうちセンサ配置節点に関する成分を取り出した スカラー, ベクトルである .

次に, 計測するモード数を $N_{\mathrm{m}}\left(N_{\mathrm{m}}<N_{\text {mall }}\right)$ とし，(1) 式右辺を計測対象モード, センサ配置時に考慮する残余モ一 ド，およびセンサ配置時に考慮しない残余モードに関する 成分に分割する。

$$
\overline{\ddot{u}}=\left\{\bar{\Phi}_{\mathrm{m}}\right\}\left\{\ddot{\eta}_{\mathrm{m}}\right\}+\left\{\bar{\Phi}_{\mathrm{um}}\right\}\left\{\ddot{\eta}_{\mathrm{um}}\right\}+\left\{\bar{\Phi}_{\mathrm{um} 2}\right\}\left\{\ddot{\eta}_{\mathrm{um} 2}\right\}
$$

ここで, $\left\{\bar{\Phi}_{\mathrm{m}}\right\}: 1 \times N_{\mathrm{m}},\left\{\bar{\Phi}_{\mathrm{um}}\right\}: 1 \times N_{\mathrm{um}},\left\{\bar{\Phi}_{\mathrm{um} 2}\right\}:$ $1 \times N_{\mathrm{um} 2}$ であり， $N_{\mathrm{um}}$ はセンサ配置時に考慮する残余モ一 ドのモード数， $N_{\mathrm{um} 2}$ はセンサ配置時に考慮しない残余モ一 ドのモード数を表す . (2) 式右辺第 3 項に対応する, セン サ配置時に考慮しない残余モード成分は帯域通過フィルタ によって完全に遮断されているものと仮定するとき，フィ

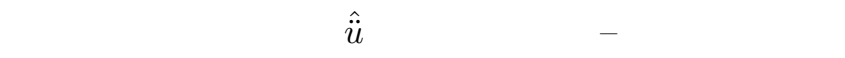
係式が次式で得られる。

$$
\hat{\ddot{u}}=\left\{\bar{\Phi}_{\mathrm{m}}\right\}\left\{\ddot{\eta}_{\mathrm{m}}\right\}+\left\{\bar{\Phi}_{\mathrm{um}}\right\}\left\{\ddot{\eta}_{\mathrm{um}}\right\}
$$

いま，センサ個数と計測対象モードの数が等しい，すな わち $N_{\mathrm{m}}=1$ であるとき, $\left\{\bar{\Phi}_{\mathrm{m}}\right\}$ および $\left\{\ddot{\eta}_{\mathrm{m}}\right\}$ はスカラー 量となり，光れ光れ $\bar{\phi}_{\mathrm{m}}$ および $\ddot{\eta}_{\mathrm{m}}$ と表すこととする. 光 して, (3) 式を $\ddot{\eta}_{\mathrm{m}}$ に関して整理すると, 次式のように計 測対象モード加速度 $\ddot{\eta}_{\mathrm{m}}$ を得る。

$$
\ddot{\eta}_{\mathrm{m}}=\frac{1}{\bar{\phi}_{\mathrm{m}}} \hat{\ddot{u}}-\frac{1}{\bar{\phi}_{\mathrm{m}}}\left\{\bar{\Phi}_{\mathrm{um}}\right\}\left\{\ddot{\eta}_{\mathrm{um}}\right\}
$$

(4) 式右辺第 2 項が残余モード成分による誤差，すなわち 観測スピルオーバである . 観測スピルオーバが微小であり 無視できるとき，(4) 式より推定モード加速度 $\ddot{\eta}_{m}^{\prime}$ が次式で 得られる．

$$
\ddot{\eta}_{\mathrm{m}}^{\prime}=\frac{1}{\bar{\phi}_{\mathrm{m}}} \hat{\ddot{u}}
$$

なお，推定モード加速度を時間に関して積分することによ り，推定モ一ド速度を得ることが可能となる.さらに，推定 モード速度を時間に関して積分することにより，推定モー ド変位が得られる。

2.1.2 加速度センサ最適配置規準 (4) 式における観測 スピルオーバが微小であるとき，(5) 式は計測対象モード 加速度の精度の高い近似式となる . (4) 式右辺第 2 項にお ける $\left\{\ddot{\eta}_{\mathrm{um}}\right\}$ は構造に作用する外力に依存するため未知の 值となるが, $\bar{\phi}_{\mathrm{m}} や\left\{\bar{\Phi}_{\mathrm{um}}\right\}$ はセンサの配置箇所によって 決定される既知の値であるため，センサ配置を変化させる ことにより観測スピルオーバの最小化が可能となる.

いま，次式のように，観測スピルオーバを誤差 $\Delta$ とおく .

$$
\Delta=\frac{1}{\bar{\phi}_{\mathrm{m}}}\left\{\bar{\Phi}_{\mathrm{um}}\right\}\left\{\ddot{\eta}_{\mathrm{um}}\right\}
$$

本研究では, 観測スピルオーバ, すなわち (6) 式で定義 した誤差を最小にするように加速度センサの配置箇所を最 適化する . (6) 式より誤差の 2 乗を求める.

$$
|\Delta|^{2}=\frac{1}{\bar{\phi}_{\mathrm{m}}^{2}}\left\{\ddot{\eta}_{\mathrm{um}}\right\}^{\mathrm{T}}\left\{\bar{\Phi}_{\mathrm{um}}\right\}^{\mathrm{T}}\left\{\bar{\Phi}_{\mathrm{um}}\right\}\left\{\ddot{\eta}_{\mathrm{um}}\right\}
$$

なお，任意の $\left\{\ddot{\eta}_{\mathrm{um}}\right\}$ に対して次の不等式が成り立つ. 


$$
\begin{aligned}
\lambda_{\min }\left(\frac{\left\{\bar{\Phi}_{\mathrm{um}}\right\}^{\mathrm{T}}\left\{\bar{\Phi}_{\mathrm{um}}\right\}}{\bar{\phi}_{\mathrm{m}}^{2}}\right) & \leq \frac{\left\{\ddot{\eta}_{\mathrm{um}}\right\}^{\mathrm{T}} \frac{\left\{\bar{\Phi}_{\mathrm{um}}\right\}^{\mathrm{T}}\left\{\bar{\Phi}_{\mathrm{um}}\right\}}{\bar{\phi}_{\mathrm{m}}^{2}}\left\{\ddot{\eta}_{\mathrm{um}}\right\}}{\left\{\ddot{\eta}_{\mathrm{um}}\right\}^{\mathrm{T}}\left\{\ddot{\eta}_{\mathrm{um}}\right\}} \\
& \leq \lambda_{\max }\left(\frac{\left\{\bar{\Phi}_{\mathrm{um}}\right\}^{\mathrm{T}}\left\{\bar{\Phi}_{\mathrm{um}}\right\}}{\bar{\phi}_{\mathrm{m}}^{2}}\right)
\end{aligned}
$$

ここで, $\lambda_{\min }$ および $\lambda_{\max }$ は乥れトリックスの最 小・最大固有值を表す .

(8) 式の右辺は誤差の最大值であるから，これを最小化 することで観測スピルオーバが最小となる .このときの加 速度センサ最適配置の目的関数を次式で定義する ${ }^{8)}$.

$$
J_{\mathrm{s}}=\min \lambda_{\max }\left(\frac{\left\{\bar{\Phi}_{\mathrm{um}}\right\}^{\mathrm{T}}\left\{\bar{\Phi}_{\mathrm{um}}\right\}}{\bar{\phi}_{\mathrm{m}}^{2}}\right)
$$

(9) 式を最小にする配置箇所がセンサ最適配置箇所となり， 最適配置箇所に配置された加速度センサからの応答を帯域 通過フィルタに通し, 帯域通過フィルタ通過後の加速度応 答より，(5) 式を用いて推定モード加速度を得る。

2.2 モードアクチュエータ 本研究では, 1 個の PZT 圧電アクチュエータを最適配置することによってモードア クチュエータを構筑し，モードセンサによって得られる推 定モード速度および推定モード変位を状態変数としたモー ド別状態フィードバック制御による振動制御を行う．本節 では, 初めに有限要素解析に基づいたモード座標系での運 動方程式を示し，モード別振動制御におけるアクチュエー 夕最適配置のための目的関数を定式化する.次に，LQR 制 御則に基づいて,フィードバックゲインを決定するための 定式化を行う.

2.2.1 アクチュエータ最適配置規準 有限要素解析に基 づき, 1 個の PZT 圧電アクチュエータを貼付した平板の振 動制御において，制御対象となる $i$ 次振動モードに関する 運動方程式は次式のように表される。

$$
\ddot{\eta}_{i}+2 \zeta_{i} \omega_{i} \dot{\eta}_{i}+\omega_{i}^{2} \eta_{i}=\left\{\Phi_{i}\right\}^{\mathrm{T}}\{D\} V \equiv f_{\mathrm{mc} i}
$$

ここで, $\eta_{i}$ は $i$ 次モード变位, $\left\{\Phi_{i}\right\}$ は $i$ 次固有振動モ一 ドベクトルであり， $\zeta_{i}, \omega_{i}$ は $i$ 次モードの滅衰比および固 有角振動数である. また， $f_{\mathrm{mc} i}$ は $i$ 次モ一ドに対する制御 力, $V$ は圧電アクチュエータ印加電圧, $\{D\}$ は圧電アク チュエータに単位電圧を印加したときの各節点での制御力 を表すべクトルである.ここで， $B_{i}=\left\{\Phi_{i}\right\}^{\mathrm{T}}\{D\}$ とおき， (10)式を次式のように書き改める .

$$
f_{\mathrm{mc} i}=B_{i} V
$$

(11) 式は $i$ 次モード制御力-制御入力関係式であり， $B_{i}$ は 弚れを関係づける係数である. $B_{i}$ はアクチュエータ配置箇 所をパラメータとした变数であり, 弚の值の絶対値が大き いほど $i$ 次モードに対する制御効果は高い，本研究では， アクチュエータを最適配置することにより, 効果的なモー ド別振動制御を実現する。乥こで， $i$ 次モード制御におけ
るアクチュエータ最適配置のための目的関数を次式で定義 する .

$$
J_{\mathrm{a}}=\max \left|B_{i}\right|
$$

以上の定式化より，(12) 式を最大にする配置箇所が，アク チュエータ最適配置箇所となる .

2.2.2 最適フィードバック制御則を適用したモード別振動 制御 本研究では,モードセンサによって計測されるモード 速度およびモード変位を状態変数としたモード別状態フィー ドバック制御による振動制御を行う．制御対象となる $i$ 次 モードに対するフィードバック制御力 $f_{\mathrm{mc} i}$ は, $i$ 次モード 変位 $\eta_{i}$ およびモード速度 $\dot{\eta}_{i}$ を用いて次式で与えられる。

$$
f_{\mathrm{mc} i}=-\left\{\begin{array}{ll}
G_{\mathrm{mp} i} & G_{\mathrm{mv} i}
\end{array}\right\}\left\{\begin{array}{c}
\eta_{i} \\
\dot{\eta}_{i}
\end{array}\right\}
$$

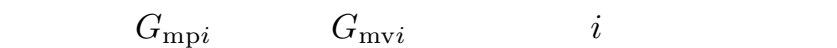
よび $i$ 次モード速度に対するフィードバックゲインである

本研究では，LQR 制御則に基づいて (13) 式における フィードバックゲインを決定する . $i$ 次モードに対する 2 次 形式評価関数 $J_{\mathrm{c} i}$ を次式で定義する.

$$
\begin{aligned}
J_{\mathrm{c} i}= & \int_{0}^{\infty}\left(\left\{x_{i}\right\}^{\mathrm{T}}\left[Q_{i}\right]\left\{x_{i}\right\}\right. \\
& \left.+\left\{f_{\mathrm{m} c i}\right\}^{\mathrm{T}}\left[R_{i}\right]\left\{f_{\mathrm{mc} i}\right\}\right) \mathrm{d} t
\end{aligned}
$$

ここで, $\left\{x_{i}\right\}=\left\{\eta_{i} \quad \dot{\eta}_{i}\right\}^{\mathrm{T}}$ は状態変数べクトルであり， モード変位 $\eta_{i}$ とモード速度 $\dot{\eta}_{i}$ を状態変数とする.ま た, $\left\{f_{\mathrm{mc} i}\right\}$ はモード制御カベクトルを表し, $\left[Q_{i}\right]=$ $\operatorname{diag}\left[\begin{array}{ll}\omega_{i}^{2} & 1\end{array}\right],\left[R_{i}\right]=r_{i}$ は制御入力に対する重み係数を表 している.(14) 式において積分内第 1 項は状態コストであ り，振動抑制の指標となる．また，第 2 項は制御コストで あり，制御入力の大きさの指標となる． $J_{\mathrm{c} i}$ を最小化する フィードバックゲインは次式で与えられるリカッチ方程式 を解くことによって得られる ${ }^{12)}$.

$$
\begin{aligned}
& {\left[P_{i}\right]\left[A_{i}\right]+\left[A_{i}\right]^{\mathrm{T}}\left[P_{i}\right]-\left[P_{i}\right]\left\{B_{i}\right\}\left\{R_{i}\right\}^{-1}\left\{B_{i}\right\}^{\mathrm{T}}\left[P_{i}\right]+\left[Q_{i}\right]} \\
& \quad=[0]
\end{aligned}
$$

ここで，

$$
\left[A_{i}\right]=\left[\begin{array}{cc}
0 & 1 \\
-\omega_{i}^{2} & -2 \zeta_{i} \omega_{i}
\end{array}\right], \quad\left\{B_{i}\right\}=\left\{\begin{array}{l}
0 \\
1
\end{array}\right\}
$$

であり， $\left[P_{i}\right]$ は対角項にフィードバックゲインを有するマト リックスである . (15) 式はモードごとに独立しているため 簡単に解くことができ, 最終的に制御対象となる $i$ 次モード に対するフィードバックゲインが次式のように求められる.

$$
\begin{aligned}
G_{\mathrm{mp} i} & =\omega_{i} \sqrt{\omega_{i}^{2}+r_{i}^{-1}}-\omega_{i}^{2} \\
G_{\mathrm{mv} i} & =\sqrt{\left(2 \zeta_{i} \omega_{i}\right)^{2}+2 G_{\mathrm{mp} i}+r_{i}^{-1}}-2 \zeta_{i} \omega_{i}
\end{aligned}
$$

これらのゲインを用いることにより，(13) 式から $i$ 次 モードに対する制御力 $f_{\mathrm{mci}}$ が求められる. 以上の定式化 により, $i$ 次モード変位およびモード速度をモードセンサ によって計測することで，モード別に独立にフィードバッ ク制御することが可能となる . 
第 1 表 CFRP 積層板の材料定数

\begin{tabular}{|c|c|c|c|c|c|c|c|}
\hline \multirow{2}{*}{$\begin{array}{c}E_{11} \\
{[\mathrm{GPa}]}\end{array}$} & \multirow{2}{*}{$\begin{array}{c}E_{22} \\
{[\mathrm{GPa}]}\end{array}$} & \multirow{2}{*}{$\begin{array}{c}G_{12} \\
{[\mathrm{GPa}]}\end{array}$} & \multirow{2}{*}{$\nu_{12}$} & \multirow{2}{*}{$\begin{array}{c}\rho \\
{\left[\mathrm{kg} / \mathrm{m}^{3}\right]}\end{array}$} & \multirow{2}{*}{$\begin{array}{c}\text { Thickness } \\
{[\mathrm{mm}]}\end{array}$} & \multicolumn{2}{|c|}{ Damping } \\
\hline & & & & & & $\alpha$ & $\beta$ \\
\hline 130.7 & 9.0 & 5.0 & 0.35 & 1,613 & 0.86 & 1.0 & $5.0 \times 10^{-6}$ \\
\hline
\end{tabular}

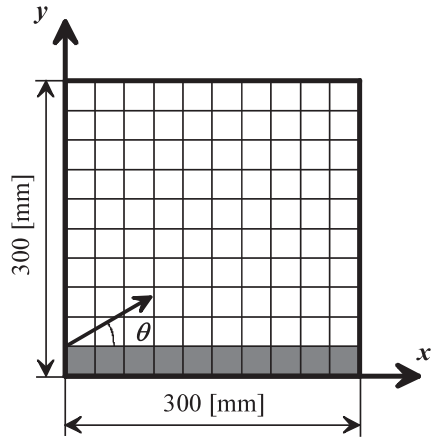

第 1 図 片持対称積層板

\section{3. 数值計算例および考察}

以降では, 本研究において提案する設計方法に基づいて 構築したモードセンサの振動計測・振動制御における有効 性に関して, 数值シミュレーション・実験の両面から検討 を行う.初めに，本章では，片持支持された CFRP 対称積 層板を対象とした振動計測の数值シミュレーションを行い， 構築した振動計測系を用いた際のモード速度推定精度につ いて検討する .

3.1 数值計算モデル 本研究で対象とする片持平板の 有限要素モデルを第 1 図に示す . 平板は $[0 / 45 /-45 / 90]_{\mathrm{S}}$ の積層構成を有する CFRP 対称積層板によって構成され， CFRP 一方向材の材料定数, 積層板の板厚および比例減衰 係数を第 1 表に示す. 構造解析において, 古典積層理論に 基づく有限要素解析に用いる要素は, 4 節点 12 自由度四 辺形板曲げ要素とする . 構造物が有する減衰は比例減衰を 仮定し, 減衰マトリックス $[C]$ は $[C]=\alpha[M]+\beta[K]$ と する．ここで， $[M]$ は質量マトリックス， $[K]$ は剛性マト リックスであり, 減衰係数 $\alpha, \beta$ は振動実験結果に基づき パラメトリックに変動させて決定している.また，第 1 図 において，黑塗りされた部分が固定支持部分を示しており， $y=0$ において全自由度固定, $y=30$ において $z$ 軸方向 変位および $y$ 軸周りの回転固定であり, $\theta$ は積層板の繊維 角を表す. なお, 数值シミュレーションによる時間履歴計 算はデュアメル積分によって行う.

本研究では, 加速度センサを用いることによりモードセ ンサを構筑する. 数值シミュレーションにおいて, 加速度 センサは有限要素節点上に配置され, 配置䇢所における面 外方向 ( $z$ 方向) 加速度を計測する. 平板に貼付するセンサ の質量・岡性は共に微小であり, 平板の振動特性に影響を与 えないものと仮定し, センサの質量・岡性は無視して数值シ ミュレーションを行う. また, 平板の片面のみに貼付された PZT 圧電素子をアクチュエータとして用いる．PZT 圧電 素子の寸法および材料定数を第 2 表に示す．ここで, 圧電
第 2 表 PZT の材料定数

\begin{tabular}{ccccc}
\hline $\begin{array}{c}d_{31} \\
{[\mathrm{pm} / \mathrm{V}]}\end{array}$ & $\begin{array}{c}E \\
{[\mathrm{GPa}]}\end{array}$ & $\nu$ & $\begin{array}{c}\rho \\
{\left[\mathrm{kg} / \mathrm{m}^{3}\right]}\end{array}$ & $\begin{array}{c}\text { Thickness } \\
{[\mathrm{mm}]}\end{array}$ \\
\hline-185 & 59.0 & 0.34 & 7,700 & 1.0 \\
\hline
\end{tabular}

材料の岡性および圧電定数は面内等方性を仮定する.なお， PZT 圧電素子の寸法は平板の有限要素解析における 1 要素 分の寸法に相当し, 数值シミュレーションでは表面に貼付 した圧電素子の質量・岡性を共に考慮する．また，PZT 圧 電素子に対する印加電圧は，4 章において振動計測・制御 実験で使用するピエゾドライバの出力電圧制限に合わせて $\pm 75 \mathrm{~V}$ までとしている.さらに, 帯域通過フィルタとして デジタルフィルタを構築し , フィルタ係数は MATLAB ${ }^{\circledR}$ の Filter Design Toolbox を用いて決定する . 構筑するデ ジタル帯域通過フィルタの特性および遮断周波数は，4 章 において使用する帯域通過フィルタ（(株) 小野測器，バ ンドパスフィルタアンプ, AU-3100) の仕樣 ${ }^{13)}$ に準拠する ものとし，4 次バタワース型帯域通過フィルタを構築する。 本研究では, 低域および高域の遮断周波数をとれ炎れ $f_{\mathrm{CL}}$, $f_{\mathrm{CH}}$ と定義し, 計測・制御対象とした $i$ 次モードが有する 固有振動数 $f_{i}$ を通過帯域に含むように設定する.

$$
f_{\mathrm{CL}}<f_{i}<f_{\mathrm{CH}}
$$

本研究では, 平板に与える加振力 ${ }^{14)}$ として以下の 3 種類 を考える.

・ステップ波 : 任意の 1 点に初期変位を与え，关れを瞬間 的に開放することで加振する.

・インパルス波 : 短時間の打撃力を想定した半波正弦波を 作用させることにより加振する .

・擬似ランダム波 : 平板の任意の要素に貼付した PZT 圧電 アクチュエータに対して , 次式で表される電圧 $V_{\mathrm{rnd}}(t)[\mathrm{V}]$ を常時印加することにより定常的に加振する．

$$
V_{\text {rnd }}(t)=A \times F(t)
$$

ただし，

$$
\begin{aligned}
& F(t)=\sum_{i=1}^{n}\left\{\sin \left(\omega_{i} t+2 \pi N_{i}\right)\right\}, \\
& A=\frac{50}{\max |F(t)|}
\end{aligned}
$$

ここで, $N_{i}$ は Box-Muller 法により求められる正規分布乱 数である.また， $n$ は擬似ランダム波を構成する最大モ一 ド次数であり, 本研究では $n=10$ として擬似ランダム波 を生成する.なお，(21) 式において乱数を変数として用い ているために, 擬似ランダム波電圧の再現性はないことに 注意を要する . 
3.2 モードセンサによるモード速度計測＼cjkstart本節では, 低 次および高次の単一振動モードのモード速度推定を行い, 主 にセンサ最適配置の重要性, 帯域通過フィルタの効果, お よび加振力の相違が推定精度におよぼす影響について検討 する .

3.2.1 1 次モード単一計測 計測対象モードを 1 次モー ド (1 次曲げモードに対応)，スピルオーバとして考慮する 残余モードを 2 次および $2 \sim 3$ 次モードとし，(9) 式に基づ く最適化により得られたセンサの最適配置箇所を，振動計 測におけるセンサ配置箇所の重要性を検討するために無作 為に決定した配置箇所 (基準配置とする) と併せて第 2 図 (a) に示す.ここで，のおよびロは光れ光れ残余モードとし て 2 次および 2 3 次モードを考慮した場合に得られるセ ンサ最適配置箇所（最適配置Ｉおよび II とする），○はセ ンサ基準配置箇所を示す．

初めに , ステップ波で表される加振力が作用する場合を 考える.第 3 図中の A 点に与えた $2 \mathrm{~mm}$ の初期変位を瞬間 的に開放することにより平板を励振した場合に関して，第 2 図 (a) に示す最適配置 I (2 次モードを考慮) および基準 配置に貼付された加速度センサを用いて 1 次モード速度を 推定する.帯域通過フィルタにおける遮断周波数を, 1 次 固有振動数 $(6.8 \mathrm{~Hz})$ に対して $f_{\mathrm{CL}}=3 \mathrm{~Hz}, f_{\mathrm{CH}}=15 \mathrm{~Hz}$ および $f_{\mathrm{CL}}=3 \mathrm{~Hz}, f_{\mathrm{CH}}=10 \mathrm{~Hz}$ とした場合, 光れ光れ の 1 次モード速度推定結果を第 4 図および第 5 図に示す. 両図において, 実線はモードセンサによるモード速度の推 定值, 破線は有限要素解析により得られたモード速度 (正 解值とする) を乥れ光れ示している．これらの図より，セ ンサを基準配置箇所に配置した場合, 帯域通過フィルタの 遷移域に含まれる残余モードに対してフィルタの遮断効果 が低下し，観測スピルオーバが生じることにより 1 次モー ド速度の推定精度が悪くなる一方, 最適配置箇所に配置す

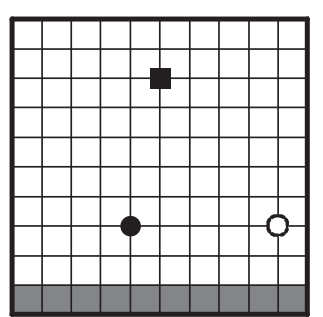

(a)

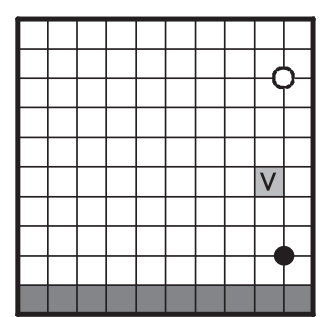

(b)
第 2 図 センサ配置箇所

(a) 計測対象 : 1 次モード, (b) 計測対象 : 4 次モード.

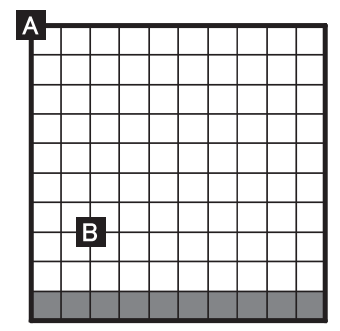

第3図 加振力作用点
ることにより推定精度が大幅に改善されていることがわか る.また，第 5 図より, 計測対象である 1 次モードに対し て帯域通過フィルタの高域遮断周波数 $f_{\mathrm{CH}}$ を小さく設定 した場合においても，センサ配置箇所の最適化による推定 精度の向上が確認できる.しかし，第 4 図 (b) および第 5 図 (b) の比較より, フィルタ高域遮断周波数 $f_{\mathrm{CH}}$ がモード

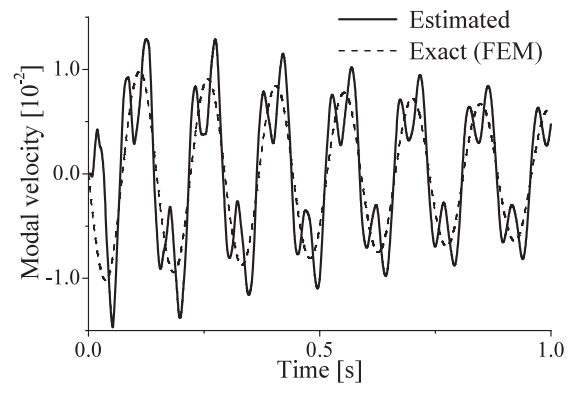

(a)

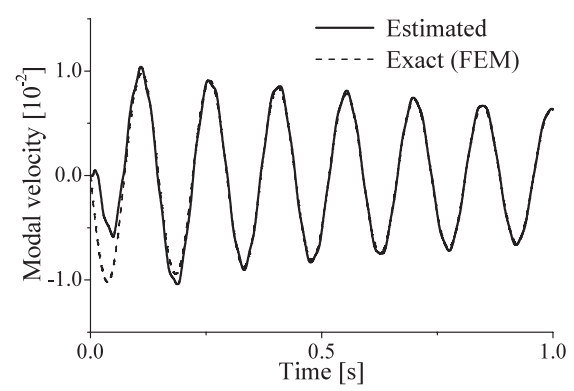

(b)

第 4 図 1 次モード速度計測結果 $\left(f_{\mathrm{CH}}=15 \mathrm{~Hz}\right.$, 加振力 : ステップ波)

(a) 基準配置，(b) 最適配置 I .

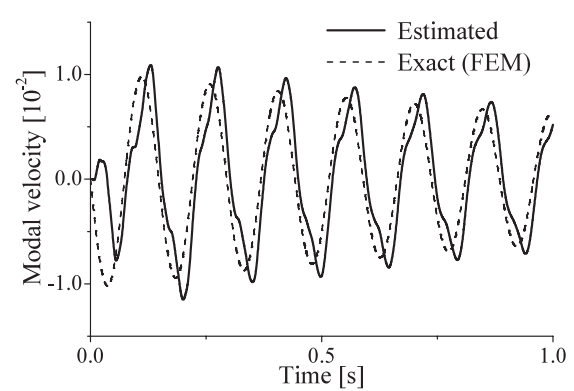

(a)

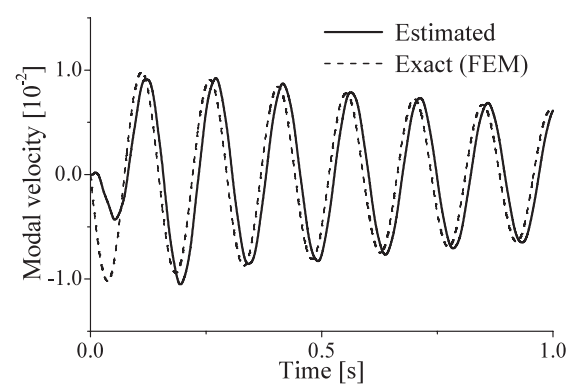

(b)

第 5 図 1 次モード速度計測結果 $\left(f_{\mathrm{CH}}=10 \mathrm{~Hz}\right.$, 加振力 : ステップ波)

（a）基準配置，(b) 最適配置 I 


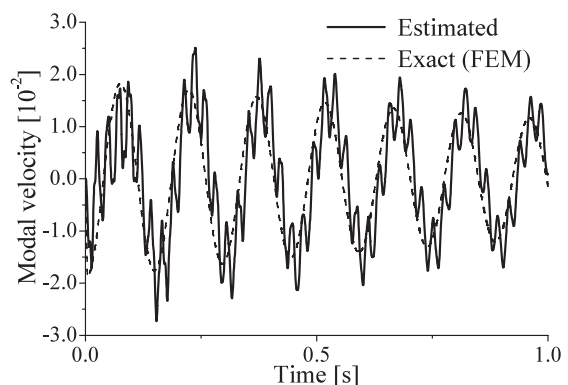

(a)

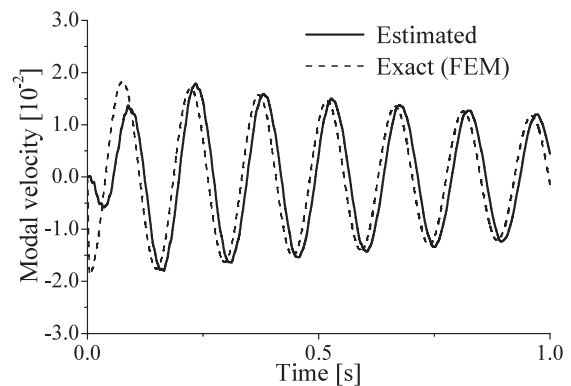

(b)

第6图 1 次モード速度計測結果（加振力：インパルス波) (a) 最適配置 I , (b) 最適配置 II

推定結果に生じる位相差の大きさに影響することがわかる . これは, 帯域通過フィルタが有する位相対周波数特性によ るものであり，計測対象モードに生じる位相差はフィルタ の遮断周波数に依存する.よって，モードセンサの設計に おいて, 計測対象モードおよび残余モードの固有振動数と 帯域通過フィルタの遮断周波数の関係を十分に考慮する必 要がある.

次に，インパルス波で表される加振力によって振動か甡じ た際の 1 次モード速度推定について検討する.ここでは，第 3 図中のB 点に, $100 \mathrm{~Hz}$ の周波数成分を有するピーク值 $10 \mathrm{~N}$ の半波正弦波を作用させることにより平板を励振する .な お，加振周波数 $100 \mathrm{~Hz}$ は，片持支持された $[0 / 45 /-45 / 90]_{\mathrm{s}}$ 積層板の 5 次モードと 6 次モードの間の周波数である . こ のとき, 帯域通過フィルタの遮断周波数と 1 次固有振動数 $(6.8 \mathrm{~Hz})$ との関係を $3 \mathrm{~Hz}<6.8 \mathrm{~Hz}<10 \mathrm{~Hz}$ とし, 第 2 図 (a) に示す最適配置 I (2 次モードを考慮) および最適配置 II (2〜3 次モードを考慮) の箇所に貼付したセンサを用い た場合の 1 次モード速度推定結果を第 6 図に示す .この図 からわかるように, 高次モードか淤起されるような加振力 が作用する場合には, より高次の残余モードをも考慮して 得られた最適配置箇所へセンサを配置する必要があるもの の，適切な箇所にセンサを配置することにより，精度良い 1 次モード速度推定が可能となっている．なお，1個のセン サによって考慮できる残余モードの数は限られ，センサ最 適配置の際には注意を要する ${ }^{15)}$.

3.2.2 高次モード単一計測 ここでは, 高次モードとし て4次モード (2 次ねじりモードに対応) を対象としたモ一 ド計測を行う . 計測対象モードを 4 次モード , スピルオー バとして考慮する残余モードを 3,5 次モードとして求め

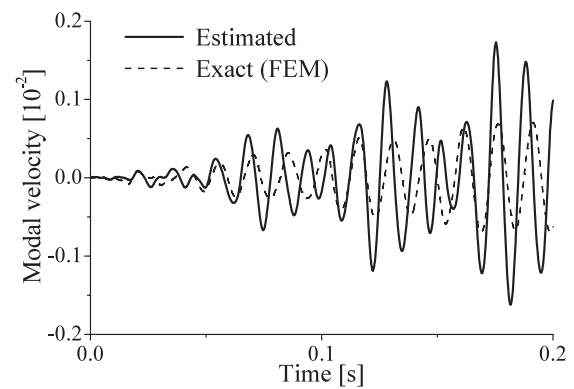

(a)

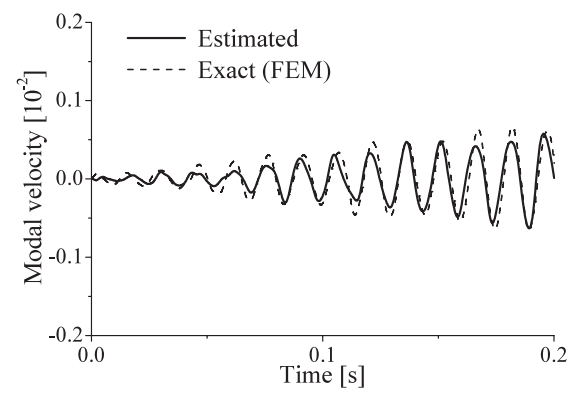

(b)

第 7 図 4 次モード速度計測結果 (加振力 : 擬似ランダム波) (a) 基準配置，(b) 最適配置 .

たセンサ最適配置箇所をセンサ基準配置箇所および加振用 アクチュエータ配置箇所と併せて第 2 図 (b) に示す.ここ で, ○はセンサ最適配置箇所 (最適配置とする)，○はセン サ基準配置箇所，Vは加振用アクチュエータ配置箇所を示 す．平板に貼付した加振用アクチュエータに対して，(20) 式で定義した擬似ランダム波電圧を印加することによって 平板を励振した場合に関して，4次モード速度推定結果を第 7 図に示す .なお，このときの帯域通過フィルタの遮断周 波数は $f_{\mathrm{CL}}=60 \mathrm{~Hz}, f_{\mathrm{CH}}=80 \mathrm{~Hz}$ とし，4 次モード (約 $69.1 \mathrm{~Hz})$ のみを通過させる設定とした $\left(f_{\mathrm{CL}}<f_{4}<f_{\mathrm{CH}}\right.$ : $60 \mathrm{~Hz}<$ 約 $69.1 \mathrm{~Hz}<80 \mathrm{~Hz})$. この图から，センサを最適 配置箇所に配置することにより，精度良い４次モ一ド速度 推定が可能となる一方, 基準配置箇所に配置した場合には 観測スピルオーバが生じることにより推定精度が悪くなる ことがわかる .

以上のことから，1 組の観測スピルオーバ最小化規準に 基づいて最適配置された加速度センサ・帯域通過フィルタ によって構築したモードセンサを用いることにより，加振 力に依存しない低次および高次の単一モードの高精度モー ド推定が可能となることが , 数值シミュレーションを通じ て明らかとなった 。

\section{4. 実験による検証}

前章では，片持支持された CFRP 対称積層板を対象とし た振動計測の数值シミュレーションを行い, 加速度センサ・ 帯域通過フィルタによって構筑したモードセンサのモード 速度推定精度について検討を行った。つづいて，本章では， 片持 CFRP 対称積層板を対象とし，構築したモードセン サを用いた振動計測・制御実験を行い，特定の低次および 


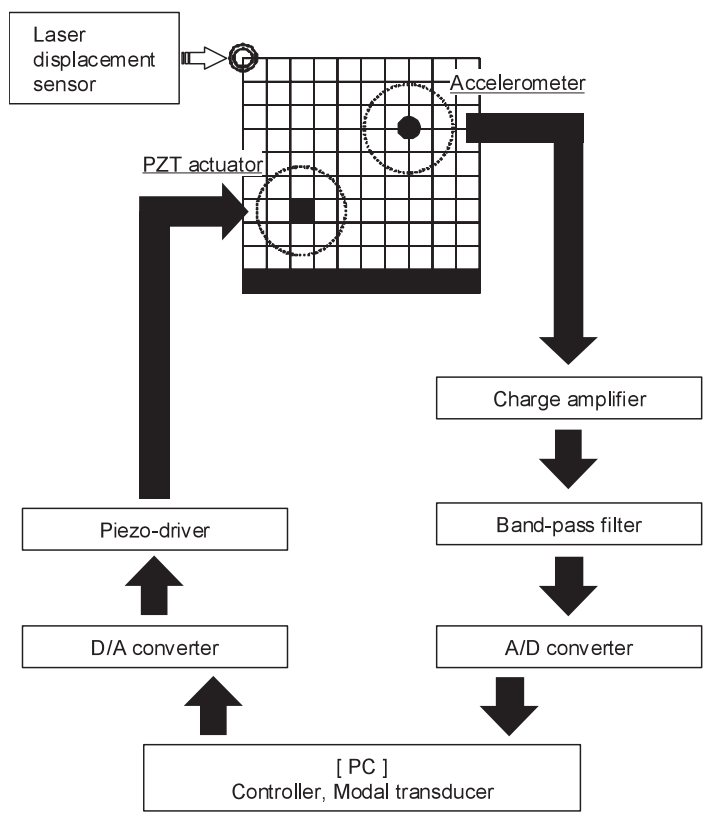

第 8 図 実験装置の概要

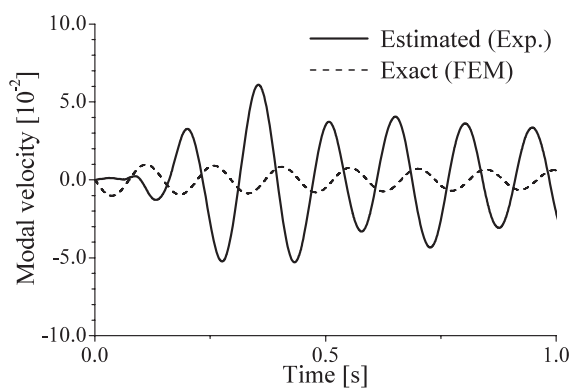

(a)

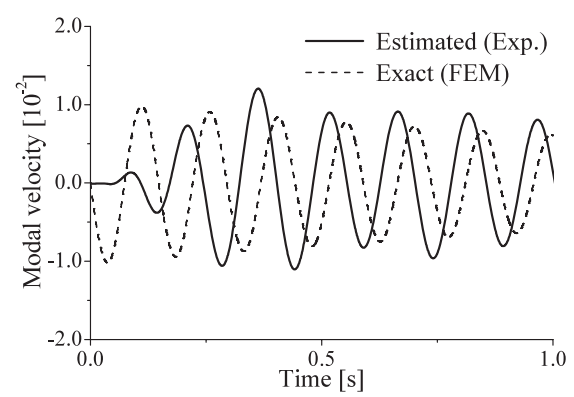

(b)

高次振動モードの計測・制御における有効性について検討 する .

4.1 実験装置 本研究で用いる実験装置の概要を第 8 図 に示す . 片持支持された平板上に貼付された加速度センサ を用い, 平板に生じる面外方向加速度を計測し, チャージ アンプによって電圧值に変換する . チャージアンプより出 カされた電圧は帯域通過フィルタへ入力され，指定した周 波数帯域の成分のみを含む電圧に変換され, $\mathrm{A} / \mathrm{D}$ 変換器に よって取得する. PC 上に構築された制御コントローラに よって制御力を求め, $\mathrm{D} / \mathrm{A}$ 変換器，ピエゾドライバによっ て増幅された制御信号が平板上に貼付された制御用 PZT ア クチュエータに入力され振動を抑制する.本研究では, 帯 域通過フィルタとして 4 次バタワース型帯域通過フィルタ を用いる．また，実験に用いるピエゾドライバの出力電圧 制限は土75V となっている。

実験に用いる供試体を第 1 图に示す.平板は $[0 / 45 /$ - 45/90]s の積層構成を有する CFRP 対称積層板によっ て構成され，CFRP一方向材の材料定数，積層板の板厚お よび比例減衰係数を第 1 表に示す. 構造物が有する減衰は 比例減衰を仮定し, 減衰係数 $\alpha, \beta$ は振動実験結果に基づ きパラメトリックに変動させて決定している．また，第 1 図において，黑塗りされた部分が固定支持部分を示してお り，固定治具により片持支持される .

4.2 モードセンサによる振動計測実験 初めに, 低次 および高次の単一振動モードのモード速度推定を行い, 主 にセンサ最適配置の重要性および加振力の相違が推定精度 におよぼす影響について検討する．

4.2.1 1 次モード単一計測 計測対象モードを 1 次モー ド (1 次曲げモードに対応)，スピルオーバとして考慮する 残余モードを $2 \sim 3$ 次モードとし，(9) 式に基づく最適化に より得られたセンサ最適配置箇所 (ロ: 最適配置 II) を, 振

第 9 図 1 次モード速度計測結果 (加振力 : ステップ波) (a) 基準配置，(b) 最適配置 .

動計測におけるセンサ配置箇所の重要性を検討するために 無作為に決定した配置箇所 (基準配置) と併せて第 2 图 (a) に示す.ここでは，センサ応答に対して適用する帯域通過 フィルタにおける遮断周波数を $f_{\mathrm{CL}}=3 \mathrm{~Hz}, f_{\mathrm{CH}}=10 \mathrm{~Hz}$ とし， 1 次モード $(6.8 \mathrm{~Hz})$ のみを通過させる設定とした $\left(f_{\mathrm{CL}}<f_{1}<f_{\mathrm{CH}}: 3 \mathrm{~Hz}<6.8 \mathrm{~Hz}<10 \mathrm{~Hz}\right)$. また, 本実験 ではステップ波で表される加振力が平板に作用する場合を 考える. 第 3 図中の A 点に与えた $2 \mathrm{~mm}$ の初期変位を瞬間 的に開放することにより平板を励振した場合に関して，第 2 図 (a) に示す最適配置箇所 (最適配置 II) および基準配 置箇所に貼付された加速度センサを用いて 1 次モード速度 を推定する.このときの 1 次モード速度推定結果を第 9 図 に示す. 第 9 图に示した 1 次モード速度推定結果において， 実線はモードセンサによるモード速度の推定値を，破線は 有限要素解析によって得られたモ一ド速度 (正解値とする) を㚇れ枈れ示している．この図より，センサを最適配置箇 所に配置することによって推定精度の大幅な改善が可能で あり，センサ配置箇所を最適化することの重要性がわかる ただし，第 9 図より，実験による推定値と有限要素解析に 基づく正解値との間に大きな位相差が確認できる .この位 相差の原因として，モードセンサとして用いている帯域通 過フィルタ，および大まかな雑音を除去するために PC 内 で用いているデジタル高域通過フィルタが有する位相対周 波数特性の影響が考えられる.しかし, 第 9 図における推 定值と正解值とを比較すると, 両者の 1 次モ一ド速度の周 期および振幅はほぼ等しく, 精度良い1 次モード推定が実 現できている.なお，この位相差に関しては，推定モード 速度・モード变位を用いたモード別振動制御の際に制御効 果を低下させる原因となり得るが, 帯域通過フィルタの位 


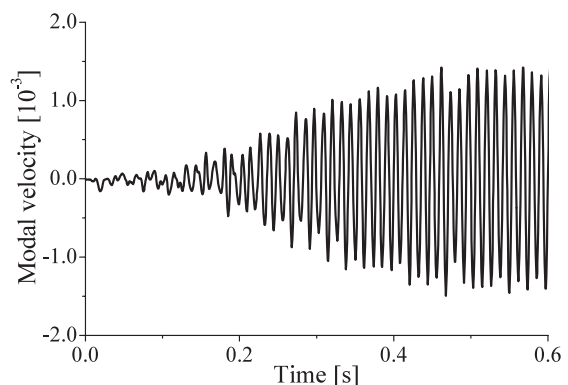

(a)

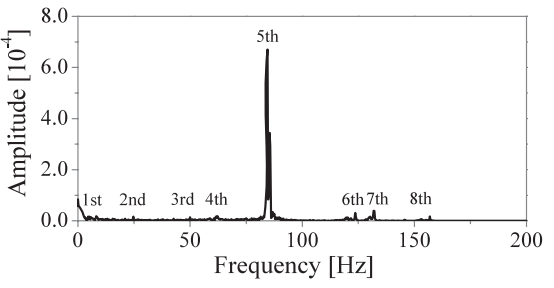

(b)

第 10 図 4 次モード速度計測結果（加振力：擬似ランダム波， センサ基準配置)

(a) 4 次モード速度の時間履歴, (b) 4 次モード速度 の FFT 解析 .

相対周波数特性に基づいて調整可能である . 以上のことか ら，センサ最適配置に基づき構筑したモードセンサを用い ることにより加振力に依存しない高精度 1 次モード推定が 可能であることを，実験によって確認できた .

4.2 .2 高次モード単一計測 ここでは, 高次モードとし て 4 次モード (2 次ねじりモードに対応) を対象とした単 一モード計測を行う. 計測対象モードを 4 次モード，スピ ルオーバとして考慮する残余モードを 3,5 次モードとし て求めたセンサ最適配置箇所をセンサ基準配置箇所および 加振用アクチュエータ配置箇所と併せて第 2 図 (b) に示す. 平板に貼付した加振用アクチュエータに対して，(20) 式で 定義した擬似ランダム波電圧を印加することによって平板 を励振した場合に関して，4 次モード速度推定結果を，推 定された 4 次モード速度の FFT 解析結果と併せて第 10 図 および第 11 図に示す.なお，このときの帯域通過フィル 夕の遮断周波数と 4 次固有振動数 (約 $67.7 \mathrm{~Hz}$ ) との関係 は， $60 \mathrm{~Hz}<$ 約 $67.7 \mathrm{~Hz}<80 \mathrm{~Hz}$ としている.第 10 図よ り, センサを基準配置箇所に配置した場合においては, 計 測対象ではない 5 次モード成分を強く含む推定結果が得ら れており, 推定精度は低いことがわかる.一方，第 11 図よ り, センサを最適配置箇所に配置することにより残余モ一 ド成分は低減され 4 次モード速度の推定精度は大幅に改善 することがわかる.特に，計測対象である 4 次モードを主成 分とするモード速度推定結果が得られており, 高精度モ一 ド推定が可能となっていることがわかる．以上のことから， 高次振動モ一ドを対象とした振動計測実験においても，セ ンサ配置箇所を最適化したモードセンサを用いることによ り，比較的精度良いモード推定が可能であることが明らか となった .

以上の検討により，観測スピルオーバ最小化規準に基づ

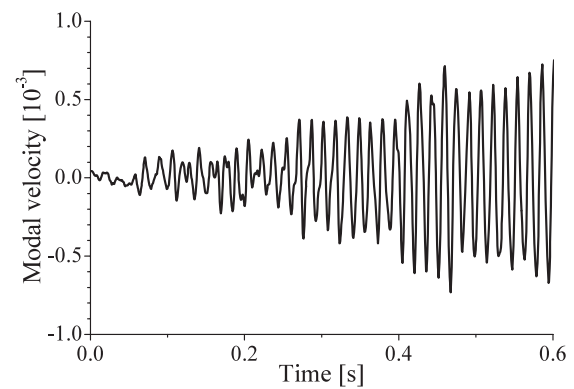

(a)

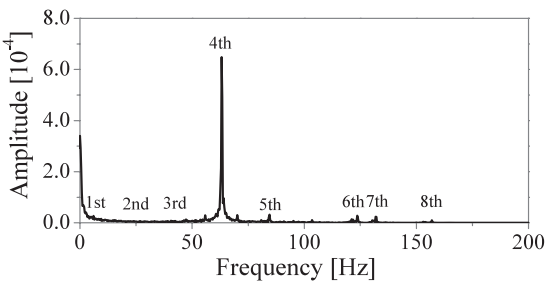

(b)

第 11 図 4 次モード速度計測結果（加振力：擬似ランダム波， センサ最適配置)

(a) 4 次モード速度の時間履歴, (b) 4 次モード速度 の FFT 解析 .

いて最適配置された 1 個の加速度センサを用いることで高 精度の低次および高次の単一モード推定が実現でき，本研 究で提案した, センサ個数の大幅な低減を可能にするモー ドセンサ設計法の有効性が実験により確認できた .

4.3 モードセンサ・アクチュエータによる振動制御実験 次に, 前節で構築したモードセンサを用いて , モード別状態 フィードバック制御による低次および高次の単一振動モー ド制御を行い, 主にセンサ最適配置の重要性および加振力 の相違が制御効果におよぼす影響について検討する .

なお，前節において述べた通り，振動計測実験において モードセンサによって得られたモード推定值に位相差が生 じることが明らかとなった，乥こで，本振動制御実験にお いては, モードセンサ内で用いている帯域通過フィルタお よび PC 内で用いているデジタル高域通過フィルタが有し ている位相対周波数特性が制御効果におよぼす影響の低減 を目的とし，予め得られるフィルタの位相対周波数特性に 基づいてフィードバック制御力の位相を PC 内にて調整す る．つまり，(13) 式で与えられた $i$ 次モードに対する制御 力 $f_{\mathrm{mci}}$ を次式のように修正する.

$$
f_{\mathrm{mc} i}(t)=-\left\{\begin{array}{ll}
G_{\mathrm{mp} i} & G_{\mathrm{mv} i}
\end{array}\right\}\left\{\begin{array}{l}
\eta_{i}(t-\tau) \\
\dot{\eta}_{i}(t-\tau)
\end{array}\right\}
$$

ここで， $\tau$ は遅れ時間であり，モード速度推定に用いる帯 域通過フィルタおよび PC 内の高域通過フィルタの有する 位相対周波数特性のみにより予め決定される定数である.

4.3.1 1 次モード単一制御 初めに, 1 次モードを対象 とした振動制御について検討を行う. 制御対象モードを 1 次モードとし，(12) 式に基づく最適化により得られたアク チュエータ最適配置箇所を, センサ配置箇所と併せて第 12 図 (a)に示す．ここで，Cはアクチュエータ最適配置箇所を 


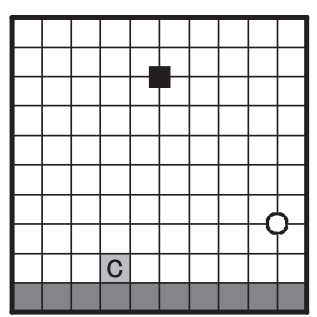

(a)

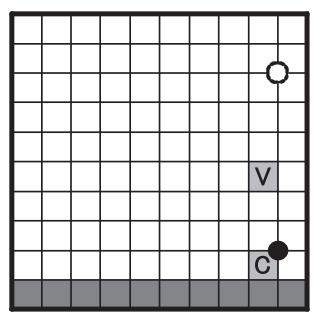

(b)
第 12 図 アクチュエータ配置箇所

(a) 制御対象: 1 次モード, (b) 制御対象: 4 次モード.

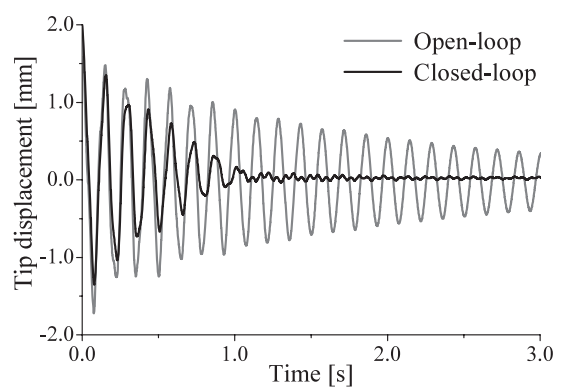

(a)

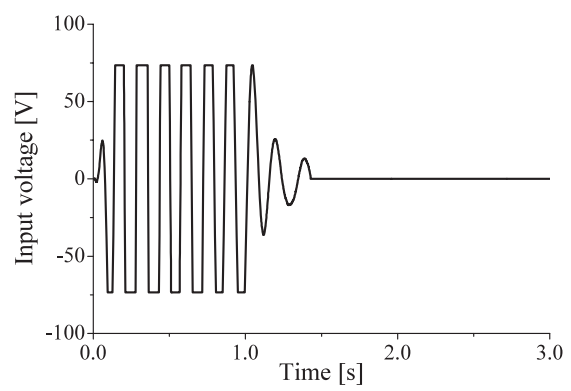

(b)

第 13 図 1 次モード制御結果 (加振力: ステップ波, センサ最適配置) (a) 面外変位の時間履歴, (b) アクチュエータ印加電圧の時 間履歴 .

示す. また, センサからの加速度応答に対して適用する帯 域通過フィルタの遮断周波数を $f_{\mathrm{CL}}=3 \mathrm{~Hz}, f_{\mathrm{CH}}=10 \mathrm{~Hz}$ とし，1 次モード (約 $6.8 \mathrm{~Hz}$ ) のみを通過させる設定とす る $\left(f_{\mathrm{CL}}<f_{1}<f_{\mathrm{CH}}: 3 \mathrm{~Hz}<\right.$ 約 $\left.6.8 \mathrm{~Hz}<10 \mathrm{~Hz}\right)$.ここ では, ステップ波で表される加振力が平板に作用する場合 を考える. 平板の振動は，第 3 図中の A 点に与えた $2 \mathrm{~mm}$ の初期变位を瞬間的に開放することにより励起する。

$\mathrm{LQR}$ 制御則の制御入力に対する重み係数 $r_{1}$ を $10^{-2}$ と した場合に，第 12 図 (a) に示すセンサ最適配置および基準 配置にセンサを貼付した際の振動制御結果を第 13 図およ び第 14 図に关れ光れ示す . 両図 (a) は, 初期変位を与えた 節点 (第 3 図中の A 点) における面外変位の時間履歴であ り，灰色の実線は開ループ系の場合，黑色の実線は閉ルー プ系の場合を表している.また，両図 (b) は閉ループ系の場 合におけるアクチュエータ印加電圧の時間履歴である .こ れらの図より, 配置箇所の最適化に基づき構築したモード センサ・アクチュエータを用いて 1 次モード制御を行うこ とにより，効果的な振動の抑制が可能であることがわかる．

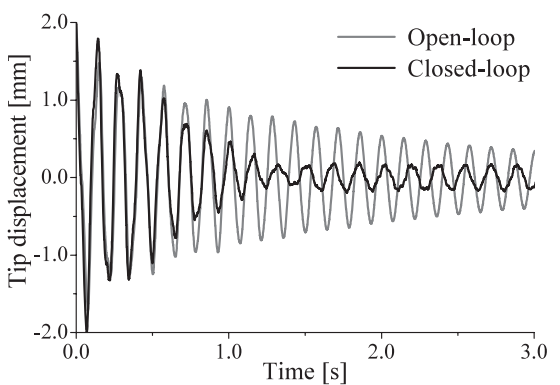

(a)

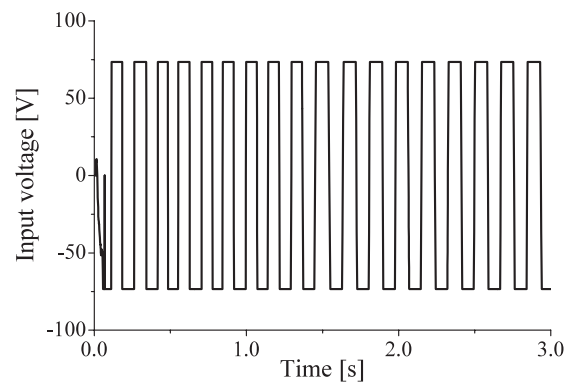

(b)

第 14 図 1 次モード制御結果 (加振力 : ステップ波, センサ基準配置) (a) 面外変位の時間履歴, (b) アクチュエータ印加電圧の時 間履歴.

また , アクチュエータ印加電圧は時間とともに収束してお り，安定した振動制御が実現できている．一方，センサを 基準配置箇所に配置した場合，振動はある程度抑制できて いるもののアクチュエータ印加電圧が発散していることか ら，振動制御が不安定になっていることがわかる．これは， センサが最適配置されていないためにモードセンサの計測 精度が低く観測スピルオーバが生じるためであると考えら れる.したがって, 効果的な振動制御を実現するには適切 に設計されたモードセンサを用いる必要があり，センサの 最適配置を行うことにより観測スピルオーバを抑制するこ とが重要であることがわかる．なお，第 13 図 (b) に示す ように, アクチュエータ印加電圧は 1.5 秒付近以降におい て 0 となっている.これは, 1 次モード速度を閾値に用い て , 1 次モード速度の振幅が規定值（ここでは 1 次モード 速度の最大振幅の $1 / 20)$ 以下となった時点で制御停止処理 を行ったことによる．

4.3 .2 高次モード単一制御 次に，4 次モードを対象と した振動制御について検討を行う．制御対象モードを 4 次 モードとし，(12) 式に基づく最適化により得られた制御用 アクチュエータ最適配置箇所を, センサ配置箇所および加 振用アクチュエータ配置箇所と併せて第 12 図 (b) に示す. ここで，平板に貼付した加振用アクチュエータに対して， (20) 式で定義した擬似ランダム波電圧を入力することによ り，平板を励振する．また，加速度センサから直接得られ る加速度応答に対して適用する帯域通過フィルタの遮断周 波数と 4 次固有振動数（約 $67.7 \mathrm{~Hz}$ ) との関係を $60 \mathrm{~Hz}<$ 約 $67.7 \mathrm{~Hz}<80 \mathrm{~Hz}$ とする.

LQR 制御則の制御入力に対する重み係数 $r_{4}$ を $10^{-2}$ と 


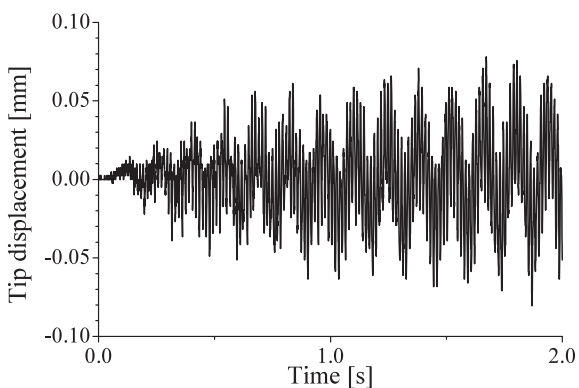

(a)

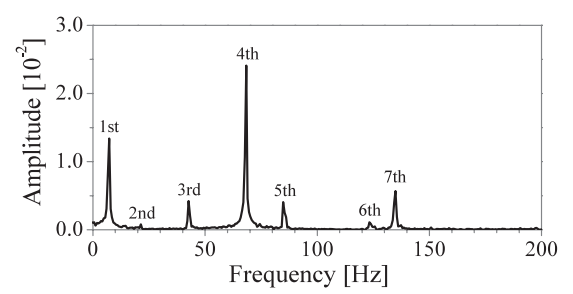

(b)

第 15 図 積層板の振動特性 (加振力 : 擬似ランダム波) (a) 面外変位の時間履歴, (b) 面外变位の FFT 解析 .

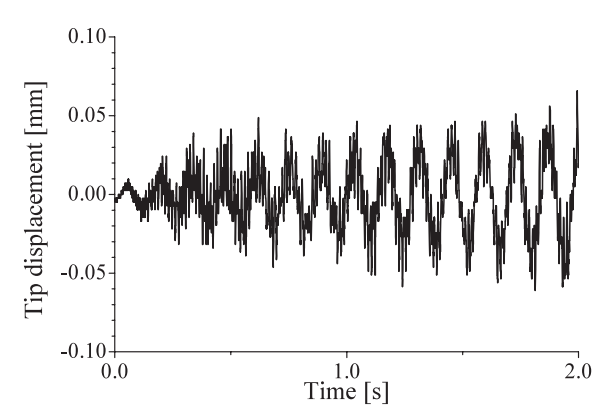

(a)

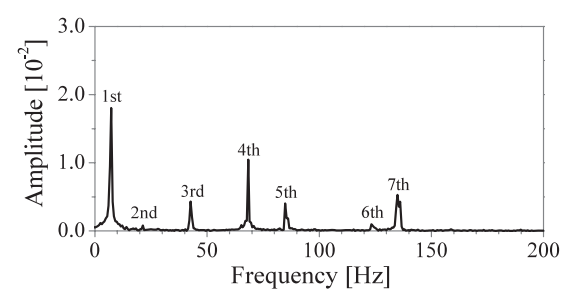

(b)

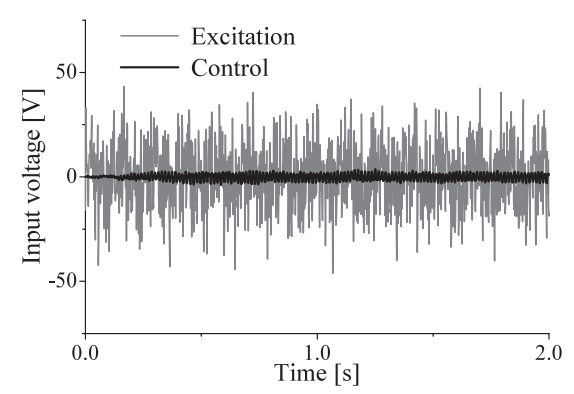

(c)

第 16 図 4 次モード制御結果 (加振力: 擬似ランダム波,$r_{4}=10^{-2}$, センサ最適配置)

(a) 面外变位の時間履歴, (b) 面外变位の FFT 解析, (c) ア クチュエータ印加電圧の時間履歴 .

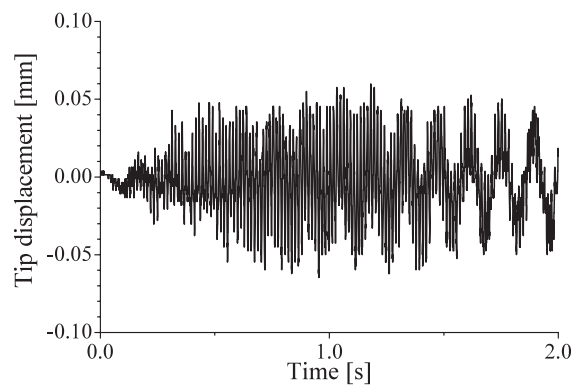

(a)

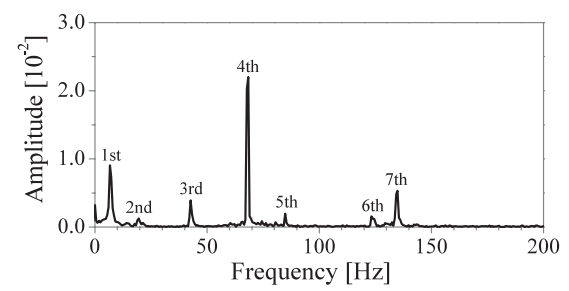

(b)

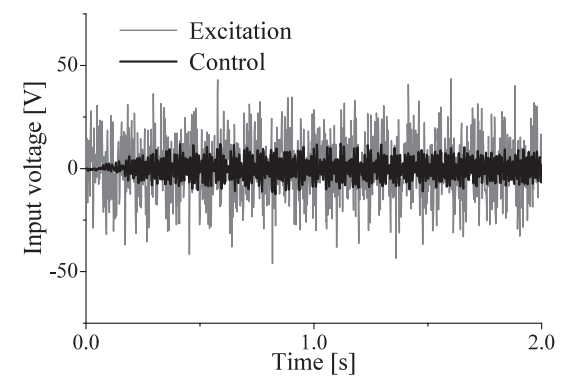

(c)

第 17 図 4 次モード制御結果 (加振力 : 擬似ランダム波,$r_{4}=10^{-2}$, センサ基準配置)

(a) 面外変位の時間履歴, (b) 面外変位の FFT 解析, , (c) ア クチュエータ印加電圧の時間履歴 .

し , 第 12 図 (b) に示すセンサ最適配置箇所にセンサを貼付 した場合に関して, 平板角 (第 1 図の $x=0, y=300 \mathrm{~mm}$ の点) の面外方向変位の時間履歴, および面外方向変位の 時間履歴の FFT 解析結果を第 15 図および第 16 図に示す。 第 15 図，第 16 図は光れ光れ開ループ系, 閉ループ系の 場合であり，閉ループ系の場合の加振用および制御用アク チュエータ印加電圧を第 16 図に併せて示す.第 16 図 (c) において, 黑色の実線が制御用アクチュエータ, 灰色の実 線が加振用アクチュエータへの印加電圧を示す .これらの 図より，比較的小さいアクチュエータ印加電圧によって 4 次モード振動の効果的な抑制が実現できていることがわか る、また，第 15 図 (b) および第 16 図 (b) の比較より，4 次以外の振動モードがほとんど減衰しておらず, 制御対象 である 4 次モードのみに対して効果的な振動制御が実現で きていることがわかる．なお，擬似ランダム波生成に際し ては, Box-Muller 法に基づく正規分布乱数を用いているた め, 開ループ系の場合と閉ループ系の場合の間で加振力は 異なることに注意を要する。

次に , 第 12 図 (b) に示すセンサ基準配置箇所にセンサを 配置した場合の 4 次モード制御結果を第 17 図に示す .この 図より，センサを基準配置箇所に配置した場合，4 次モー 


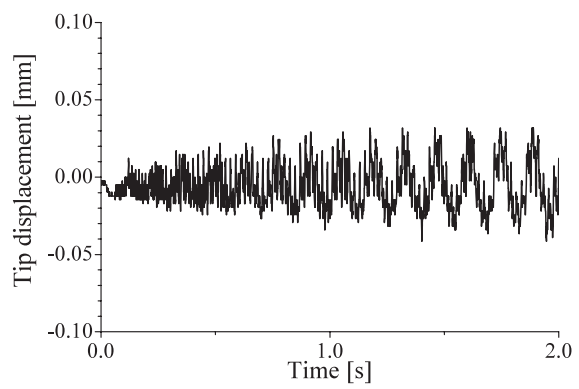

(a)

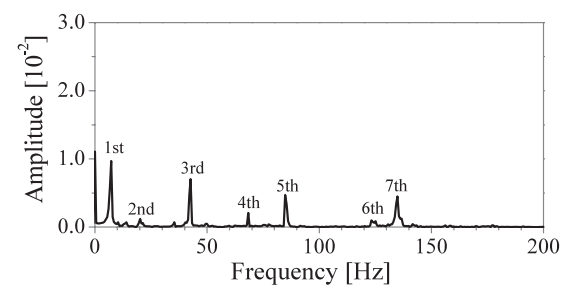

(b)

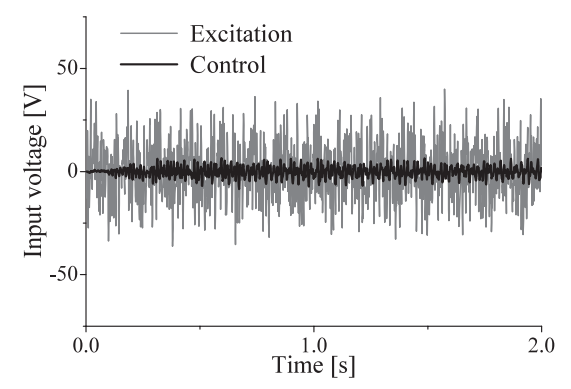

(c)

第 18 図 4 次モード制御結果 (加振力:擬似ランダム波,$r_{4}=5 \times 10^{-3}$, センサ最適配置)

(a) 面外変位の時間履歴, (b) 面外変位の FFT 解析 , (c) ア クチュエータ印加電圧の時間履歴

ドの抑制は可能ではあるが, センサ最適配置の場合と比較 して 2 倍程度の制御用アクチュエータ印加電圧を印加して いるにもかかわらず，4 次振動モードに対する制御効果は 低いことがわかる．このことから，高次モードを制御対象 とした場合に関しても，安定かつ効果的な振動制御を実現 するためには, モードセンサによるモード速度・モード変 位の高精度推定が重要となることが明らかとなった．

また，LQR 制御則の制御入力に対する重み係数 $r_{4}$ を $5 \times 10^{-3}$ とした場合の制御効果について検討を行う. 第 12 図 (b) に示すセンサ最適配置箇所にセンサを配置して 4 次 モード制御を行った場合の制御結果を第 18 図に示す.第 16 図との比較より， $r_{4}$ の值を小さくすることによって 4 次 モードのさらなる抑制が可能であり，この場合においても， スピルオーバ不安定は起きていないことがわかる．よって， 重み係数 $r_{4}$ を適切に設定することにより 4 次振動モード の効果的な抑制が可能である .

以上の検討により, 最適配置箇所に配置された 1 個のセ ンサおよび 1 個のアクチュエータによって低次および高次 の単一モードの安定・効果的な振動制御が実現でき, 本研 究で構築したモードセンサ・アクチュエータの振動制御に
おける有効性が実験により確認された．

$$
\text { 5. 結言 }
$$

本論文では，片持支持された CFRP 対称積層板を対象と して , 1 組の加速度センサと帯域通過フィルタ, および PZT 圧電アクチュエータを用いた低次および高次の単一モード 振動計測・振動制御に関する検討を行った . 数値計算例お よび実験例を通して，センサの観測スピルオーバ最小化規 準に基づく最適配置と帯域通過フィルタの適切な設定によ り, 加振力に依存しない低次および高次の単一振動モード の高精度モード推定・制御が可能であることが明らかとな り, 本研究で提案するモードセンサ設計方法の有効性が示 された .

なお，今後の課題としては, 計測対象モ一ドの固有振動 数が他のモードの固有振動数と近接, もしくは, 重複する 構造を対象とした振動計測・振動制御への応用, 多モード 制振への応用等が挙げられる。

\section{参 考 文 献}

1) Hyland, D. C., Junkins, J. L. and Longman, R. W.: Active Control Technology for Large Space Structures, J. Guid. Control Dynam., 16 (1993), pp. 801-821.

2) Crawley, E. F.: Intelligent Structures for Aerospace: A Technology Overview and Assessment, AIAA J., 32 (1994), pp. 1689-1699.

3) Lee, C. K. and Moon, F. C.: Modal Sensors/Actuators, J. Appl. Mech., 57 (1990), pp. 434-441.

4) Gu, Y., Clark, R. L., Fuller, C. R. and Zander, A. C.: Experiments on Active Control of Plate Vibration Using Piezoelectric Actuators and Polyvinylidene Fluoride (PVDF) Modal Sensors, J. Vib. Acoust., 116 (1994), pp. 303-308.

5) Tzou, H. S. and Hollkamp, J. J.: Collocated Independent Modal Control with Self-Sensing Orthogonal Piezoelectric Actuators (Theory and Experiment), Smart Mater. Struct., 3 (1994), pp. 277-284.

6) Tanaka, N. and Sanada, T.: Modal Control of a Rectangular Plate Using Smart Sensors and Smart Actuators, Smart Mater. Struct., 16 (2007), pp. 36-46.

7) Ryou, J. K., Park, K. Y. and Kim, S. J.: Electrode Pattern Design of Piezoelectric Sensors and Actuators Using Genetic Algorithms, AIAA J., 36 (1998), pp. 227-233.

8) Sun, D., Tong, L. and Wang, D.: Vibration Control of Plates Using Discretely Distributed Piezoelectric Quasi-Modal Actuators/Sensors, AIAA J., 39 (2001), pp. 1766-1772.

9）川畑成之, 福永久雄 : センサ・アクチュエータの最適配置に基づく CFRP 積層板の振動計測・振動制御 第 1 報 数値シミュレー ション，日本航空宇宙学会論文集，52 (2004), pp. 499-506.

10）川畑成之, 福永久雄 : センサ・アクチュエータの最適配置に基づ くCFRP 積層板の振動計測・振動制御 第 2 報 実験，日本航 空宇宙学会論文集 , 53 (2005), pp. 295-301.

11) Corr, L. R. and Clark, W. W.: A Novel Semi-Active MutliModal Vibration Control Law for a Piezoceramic Actuators, J. Vib. Acoust., 125 (2003), pp. 214-222.

12) Wang, Z., Chen, S. and Han, W.: Integrated Structural and Control Optimization of Intelligent Structures, Eng. Struct., 21 (1999), pp. 183-191.

13) (株) 小野測器 : AU-3100 バンドパスフィルタアンプ取扱説明書 2007.

14) 日本機械学会編：モード解析の基礎と応用, 丸善, 東京, 1986.

15）和田理男 : 高次振動モードを考慮した平板の振動計測・制御に関 する研究, 東北大学修士学位論文, 2008 . 